\title{
The effects of MIBG on the invasive properties of HepG2 hepatocellular carcinoma cells
}

\author{
YAN SU, XIAO-QIN GUAN, FENG-QIU LIU and YA-LAN WANG \\ Molecular Medicine and Cancer Research Center, Department of Pathology, \\ Chongqing Medical University, Chongqing, P.R. China
}

Received April 1, 2014; Accepted June 19, 2014

DOI: $10.3892 /$ ijmm.2014.1819

\begin{abstract}
The aim of the present study was to investigate the effects of meta-iodobenzylguanidine (MIBG) on the invasive properties of hepatocellular carcinoma (HCC) cells and examine whether these effects are due to the ability of MIBG to inhibit arginine-specific mono-ADP-ribosylation. Samples from patients with HCC were divided into 2 groups, a metastatic group and a non-metastatic group. Immunohistochemistry and RT-PCR were used to detect the protein and mRNA expression of arginine-specific adenosine diphosphate-ribosyltransferase 1 (ART1) and integrin $\alpha 7$ in the HCC tissues. In addition, the expression of ART1 was measured in HepG2 HCC cells by immunofluorescence. The inhibition of the metastasis of HepG2 cells by MIBG at various concentrations was measured by MTT assay. In addition, the effects of MIBG on HepG2 cell metastasis were measured using a scratch wound assay and a Transwell invasion assay. Western blot analysis was used to detect the protein expression of ART1, integrin $\alpha 7$, focal adhesion kinase (FAK), phosphatidylinositol 3-kinase (PI3K) and urokinase-type plasminogen activator (uPA) in the HepG2 cells. The mRNA and protein levels of ART1 and integrin $\alpha 7$ were higher in the metastatic HCC samples than in the nonmetastatic HCC samples. ART1 expression was detected in the HepG2 cells. The half maximal inhibition concentration $\left(\mathrm{IC}_{50}\right)$ of MIBG in the HepG2 cells was $200 \mu \mathrm{mol} / \mathrm{l}(\mathrm{P}<0.05)$. Within a certain dose range, MIBG exerted inhibitory effects on HepG2 cell migration in a dose-dependent manner. Treatment with MIBG significantly inhibited the migration and invasion of the HepG 2 cells relative to the control cells $(\mathrm{P}<0.05)$ and reduced the protein expression of ART1, integrin $\alpha 7, \mathrm{FAK}, \mathrm{PI} 3 \mathrm{~K}$ and $\mathrm{UPA}$ $(\mathrm{P}<0.05)$. Our data demonstrate that ART1 and integrin $\alpha 7$ may be involved in the invasive and metastatic properties of $\mathrm{HCC}$
\end{abstract}

Correspondence to: Professor Xiao-Qin Guan, Molecular Medicine and Cancer Research Center, Department of Pathology, Chongqing Medical University, No. 1 Yixueyuan Road, Chongqing 400016, P.R. China

E-mail: guanxiaoqin213@gmail.com

Key words: adenosine diphosphate-ribosyltransferase 1, metaiodobenzylguanidine, HepG2 cells, integrin $\alpha 7$, urokinase-type plasminogen activator, invasion, metastasis cells. MIBG inhibited the migration and invasion of HepG2 cells, possibly through the inhibition of arginine-specific singleadenosine diphosphate ribosylation and the suppression of the protein expression of integrin $\alpha 7 \beta 1$, FAK and PI3K and the secretion of uPA, leading to reduced invasion by HepG2 cells.

\section{Introduction}

Adenosine diphosphate (ADP)-ribosylation reaction refers to the process during which mono- or poly-ADP is transferred onto amino acid residues. The process is catalyzed by ADP-ribosyltransferases (ARTS) to break the glycosidic bond between nicotinamide of nicotinamide adenine dinucleotide $\left(\mathrm{NAD}^{+}\right)$and adjacent ribose $(1,2)$.

The mono-ADP-ARTS (mARTS) include 5 members, the only one of which, existing in human cells with a fixed sequence R-S-EXE of arginine-specific ARTS, is argininespecific mono-ADP-ribosyltransferase-1 (ART1) (16), which can directly modify integrin $\alpha 7 \beta 1$. As a transmembrane protein, integrin $\alpha 7 \beta 1$ is highly involved in the adhesion, invasion and metastasis of cancer cells. The modified integrin $\alpha 7 \beta 1$ is functionally upregulated, with its affinity to laminin (LN) improved (3-5).

Meta-iodobenzylguanidine (MIBG) is a type of analogue of guanidine neurotransmitter, norepinephrine, which can inhibit the function of ARTS through competitive binding of the catalytic site. As a result, MIBG can function as an ART1-specific inhibitor (6). It has been previously reported that MIBG inhibits the proliferation and metastasis of smooth muscle cells (7).

In a previous study by our group, it was demonstrated that the gene silencing of ART1 in colorectal carcinoma inhibited the expression of ART1, downregulated the expression of matrix metalloproteinase (MMP)-2 and MMP-9, inhibited their activity and eventually affected the adhesion and invasion capacity of CT26 colorectal carcinoma cells (8). Currently, however, the effects of ART and integrin $\alpha 7 \beta 1$ on the invasion and metastasis of hepatocellular carcinoma (HCC) (HepG2) cells remains unknown. Consequently, this study aimed to investigate the effects of ART and integrin $\alpha 7 \beta 1$ on the invasion and metastasis of HCC cells, as well as to determine the effects of ART1 on the expression of integrin $\alpha 7 \beta 1$, focal adhesion kinase (FAK), phosphatidylinositol 3-kinase (PI3K) and urokinase-type plasminogen activator (uPA) in HepG2 cells, after inhibiting the expression of ART1 by utilizing MIBG. 
The present study provides preliminarily relevant experimental foundation for a novel method for HCC moleculer-targeted therapy.

\section{Materials and methods}

Immunohistochemical (IHC) analysis. HCC tissue sections $(\mathrm{n}=39)$ were obtained from the Department of Pathology of the First Affiliated Hospital of Chongqing Medical University, Chongqing,China. Of these, 29 were from male patients and 10 were from female patients with the liver histological grade (Edmondson grade) distributed as follows: I-II (12 cases), III-IV (27 cases), HCC with metastasis (lymph node, blood vessel or other organs) (17 cases) and HCC without metastasis (22 patients). IHC was used to detect the expression of ART1 (Sigma, St. Louis, MO, USA) and integrin $\alpha 7$ (Beijing, Biosynthesis Biotechnology Co., Ltd., Beijing, China) in the HCC tissues according to the instructions provided with the kit. Sets of positively stained cells were divided into groups based on the antigen signal: pale yellow, weakly positive (+) 1 point; yellow, moderately positive $(++) 2$ points; brownish yellow, strongly positive $(+++) 3$ points. The slides were divided into groups based on the number of positive cells: weakly positive $(+$, refers to the number of positive cells up to $25 \%)$; moderately positive (++, refers to the number of positive cells between $25-49 \%)$; strongly positive (,$+++>50 \%$ of cells were positive). Using integrated measurement, the following calculation formula was developed and used: $(+) \%$ x $1+(++) \%$ x $2+(+++) \%$ x 3 , the total value of $<1.0$ by $(+), 1.0$ to 1.5 by $(++),>1.5$ by $(+++)$. Random observations were made for at least 5-10 high-power fields (HPFs).

RT-PCR detection of ART1 and integrin $\alpha 7 \mathrm{mRNA}$ expression. Fresh HCC samples ( 3 cases of HCC with metastasis; 3 cases of HCC without metastasis) were obtained from the Department of Hepatobiliary Surgery of the First Affiliated Hospital of Chongqing Medical University. The samples were stored in liquid nitrogen. Total RNA was extracted from the tissue samples using a One-Step RT-PCR kit (Takara, Shiga, Japan) according to the manufacturer's instructions. The primers for ART1 (XM_005252934) and integrin $\alpha 7$ (NM_001144996) were synthesized by Shanghai Sangon Biological Engineering Technology \& Services, Co., Ltd., Shanghai, China. The primer sequences were as follows: ART1 forward, 5'-CTCCATTTCC TGCTGACTGAG-3' and reverse, 5'-AGGTCCAGATGCC GAAGAAG-3'; integrin $\alpha 7$ forward, 5'-GAACTCCTCCC ACCCAACTT-3' and reverse, 5'-GACGAAACCACGAAA CCACT-3'; $\beta$-actin forward, 5'-GTCAAGAAAGGGTGTAA CGCAAC-3' and reverse, 5'-TCCTGTGGCATCCACGA AACT-3'. The PCR reaction conditions for ART1 and integrin $\alpha 7$ were as follows: 30 cycles of $94^{\circ} \mathrm{C}$ for $3 \mathrm{~min}, 94^{\circ} \mathrm{C}$ for $30 \mathrm{sec}$ and $60^{\circ} \mathrm{C}$ for $30 \mathrm{sec}$. The PCR reaction conditions for $\beta$-actin were as follows: 30 cycles of $94^{\circ} \mathrm{C}$ for $3 \mathrm{~min}, 94^{\circ} \mathrm{C}$ for $30 \mathrm{sec}, 56^{\circ} \mathrm{C}$ for $60 \mathrm{sec}$ and $72^{\circ} \mathrm{C}$ for $60 \mathrm{sec}$. After completion of the reaction, $20 \mu \mathrm{l}$ PCR reaction solution was used for electrophoresis on an agarose gel. Band intensities were measured using Quantity One software (Bio-Rad, Hercules, CA, USA), and gene amplification was defined as the ratio of the optical density (OD) of the target gene to that of the housekeeping gene, $\beta$-actin. The experiment was performed 3 times.
Cell culture. HepG2 cells were provided by the Life Science Institute of Chongqing Medical University. The cells were grown in RPMI-1640 supplemented with $10 \%$ fetal calf serum plus ampicillin $(100 \mu / \mathrm{ml})$ and streptomycin $(100 \mu \mathrm{g} / \mathrm{ml})$, at $37^{\circ} \mathrm{C}$ and $5 \% \mathrm{CO}_{2}$. MIBG (Sigma) was used to inhibit the ART1 signaling pathway.

Immunofluorescence (IF) detection of ART1 expression. The HepG2 cells $\left(1 \times 10^{6}\right.$ cells/well) were seeded into 6-well plates containing glass coverslips. When cell attachment to the glass was approximately $90 \%$ complete, the slides were removed and washed 3 times with PBS. These cells were fixed with $10 \%$ formaldehyde for $30 \mathrm{~min}$, washed 3 times with PBS for $2 \mathrm{~min}$ each, and treated with $0.5 \%$ Triton for a further $15 \mathrm{~min}$. They were then washed twice with PBS for 5 min each. The cells were then covered with $1 \%$ BSA for 30 min and incubated with 1:100 anti-ART1 antibody overnight at $4^{\circ} \mathrm{C}$. Cells exposed to PBS instead of the primary antibody served as the negative controls. The following day, the slides were washed 3 times with PBS for 5 min each. Subsequently, 1:500 rabbit anti-goat IgG/FITC-labeled antibody was added at $37^{\circ} \mathrm{C}$ in the dark for hybridization followed by incubation for $1 \mathrm{~h}$. The slides were then washed 3 times with PBS. Finally, the glass coverslips were mounted using fluorescence quenching liquid. Images were captured using a fluorescence microscope (Olympus, Tokyo, Japan) and analyzed using IPP Image software (Media Cybernetics, Inc., Rockville, MD, USA).

\section{Cell proliferation, migration and invasion assays}

Cell proliferation inhibition assay. Cell proliferation was determined by MTT assay. Briefly, the HepG 2 cells, at $10^{3}$ cells/ well, were dispensed in $100 \mu \mathrm{l}$ aliquots into 96-well plates. Subsequently, $24 \mathrm{~h}$ after inoculation, the cell culture medium was replaced with final concentrations of 50, 100, 150, 200, 250 and $300 \mu \mathrm{mol} / 1 \mathrm{MIBG}$ for $24 \mathrm{~h}$. An equal volume of DMSO was used as a negative control. After $24 \mathrm{~h}, 20 \mu 1$ MTT were added to each well followed by culture for a further $4 \mathrm{~h}$. The supernatant was then carefully aspirated. Subsequently, $150 \mu \mathrm{l}$ of DMSO were added to each well, and the plate was shaken until the purple crystals were completely dissolved. OD490 nm (A) was measured using a 680 microplate reader (Bio-Rad). The rate of inhibition of cell growth (IR) was calculated as follows: cell growth inhibition rate $(\%)=(1-\mathrm{A}$ treatment $/ \mathrm{A}$ control $) \times 100 \%$. The half maximal inhibition concentration $\left(\mathrm{IC}_{50}\right)$ of $\mathrm{IMBG}$ in the HepG2 cells was determined using $\mathrm{IC}_{50}$ calculation software (SPSS, Inc., Chicago, IL, USA).

Cell migration assay. Cell migration was evaluated using a scratch wound assay. Briefly, $5 \times 10^{5} \mathrm{HepG} 2$ cells/well were plated in 6-well plates and cultured overnight to yield a confluent monolayer. A $10-\mu 1$ pipette tip was used to scratch the bottom of the culture plates. The remaining cells were washed twice, then cultured with fresh medium supplemented with MIBG $200 \mu \mathrm{mol} / 1$, and fresh medium was used as a control medium. Images were captured at 0 and $24 \mathrm{~h}$ using an NIS-Elements Image Analysis System (Nikon Corp., Tokyo, Japan). Distance was marked at fixed intervals. Three mean values were calculated, including the width of the scratch test, according to the following formula to determine the rate at which the scratches healed. Healing rate $=$ (initial scratch width value - corresponding points scratch width)/initial value $\mathrm{x} 100 \%$ scratch width. 
Table I. Association between the pathological features of HCC and the expression of ART1 and integrin $\alpha 7$ in HCC tissues.

A, Association between pathological features of HCC and the expression of ART1 in HCC tissues

\begin{tabular}{|c|c|c|c|c|c|c|c|}
\hline \multirow[b]{2}{*}{ Pathological features } & \multirow[b]{2}{*}{$\mathrm{n}$} & \multicolumn{4}{|c|}{ Semi-quantitative grading } & \multirow[b]{2}{*}{ U value } & \multirow[b]{2}{*}{ P-value } \\
\hline & & - & + & ++ & +++ & & \\
\hline \multicolumn{8}{|l|}{ Pathological grade } \\
\hline III-IV & 27 & 0 & 9 & 11 & 6 & 2.8109 & $<0.05$ \\
\hline I-II & 12 & 4 & 6 & 2 & 1 & & \\
\hline \multicolumn{8}{|l|}{ Tumor metastasis } \\
\hline Yes & 17 & 0 & 4 & 6 & 7 & 3.4485 & $<0.01$ \\
\hline No & 22 & 4 & 11 & 7 & 0 & & \\
\hline
\end{tabular}

$\mathrm{B}$, Association between pathological features of $\mathrm{HCC}$ and the expression of integrin $\alpha 7$ in $\mathrm{HCC}$ tissues

\begin{tabular}{|c|c|c|c|c|c|c|c|}
\hline \multirow[b]{2}{*}{ Pathological features } & \multirow[b]{2}{*}{$\mathrm{n}$} & \multicolumn{4}{|c|}{ Semi-quantitative grading } & \multirow[b]{2}{*}{ U value } & \multirow[b]{2}{*}{ P-value } \\
\hline & & - & + & ++ & +++ & & \\
\hline \multicolumn{8}{|l|}{ Pathological grade } \\
\hline III-IV & 27 & 1 & 6 & 9 & 11 & 2.4627 & $<0.05$ \\
\hline I-II & 12 & 1 & 7 & 3 & 1 & & \\
\hline \multicolumn{8}{|l|}{ Tumor metastasis } \\
\hline Yes & 17 & 0 & 3 & 5 & 9 & 3.4485 & $<0.01$ \\
\hline No & 22 & 2 & 10 & 7 & 3 & & \\
\hline
\end{tabular}

Cell invasion assay. Cell invasion was evaluated using a Transwell Matrigel invasion assay. First, $10^{5}$ HepG2 cells/well suspended with RPMI-1640 were seeded in the upper chamber (Millipore Corp., Billerica, MA, USA). These were coated with Matrigel (BD Biosciences, Bedford, MA, USA) and incubated with HepG2 conditioned supernatant (MIBG $200 \mu \mathrm{mol} / 1$ in serum-free RPMI-1640, and RPMI-1640 without serum served as a control). RPMI-1640 supplemented with 10\% FBS was in the lower chamber. After $24 \mathrm{~h}$, the invading cells on the bottom surface were fixed with $4 \%$ paraformaldehyde and quantified after staining with crystal violet. The invasion inhibition rate was caclulated as follows: invasion inhibition rate $=$ (average untreated control group - average treated group)/average value for the dosing control group x $100 \%$.

Western blot analysis. Protein concentrations were evaluated using BCA protein assay reagent (Beyotime, Shanghai, China). HepG2 cells from different groups (control group, MIBG $150 \mu \mathrm{mol} / \mathrm{l}$-treated group and MIBG $200 \mu \mathrm{mol} / \mathrm{l}$ treated group) were lysed with RIPA buffer, and $25 \mu \mathrm{g}$ of total protein were separated by standard 6-10\% SDS-PAGE and transferred onto PVDF membranes. The membranes were washed and blocked with $5 \%$ skim milk at room temperature for $1 \mathrm{~h}$ before being incubated with primary antibodies to ART1 (Sigma), integrin $\alpha 7$ (Beijing Biosynthesis Biotechnology Co., Ltd., Beijing, China), FAK, PI3K and uPA (Wuhan Mitaka Biotechnology, Wuhan, China) at $4^{\circ} \mathrm{C}$ overnight. The primary antibodies were diluted as follows: ART1, 1:500; integrin $\alpha 7,1: 500$; FAK, 1:500; PI3K, 1:500;
uPA, 1:200; and $\beta$-actin, 1:1,000. An HRP-conjugated secondary anti-rabbit antibody $(1: 1,000)$ was then added for $2 \mathrm{~h}$ at room temperature. The reactions were detected by enhanced chemiluminescence assay (Beyotime Institute of Biotechnology). The relative intensity of each band was determined using Quantity One software (Bio-Rad). Each experiment was performed 3 times.

Statistical analysis. SPSS 18.0 statistical software was used for statistical analysis. The quantitative data are presented as the means \pm standard deviation (SD). Comparisons of continuous data were performed using one-way ANOVA. The rank-sum and least significant difference (LSD) test were used to analyze the ranked data and the differences between each group. The relationship between 2 groups was analyzed by correlation analysis. A value of $\mathrm{P}<0.05$ was considered to indicate a statistically significant difference.

\section{Results}

Expression of ART1 and integrin $\alpha 7$ in HCC tissues. IHC revealed the positive expression of ART1 and integrin $\alpha 7$ in the HCC tissues. Its expression was mostly observed on the cell surface and in the cytoplasm. The expression levels of ART1 and integrin $\alpha 7$ in the HCC samples with metastasis and a liver histological grade (Edmondson grade) of III-IV were significantly higher than those in the HCC samples without metastasis and a liver histological grade (Edmondson grade) of I-II ( $\mathrm{P}<0.05$; Table I, Fig. 1). 


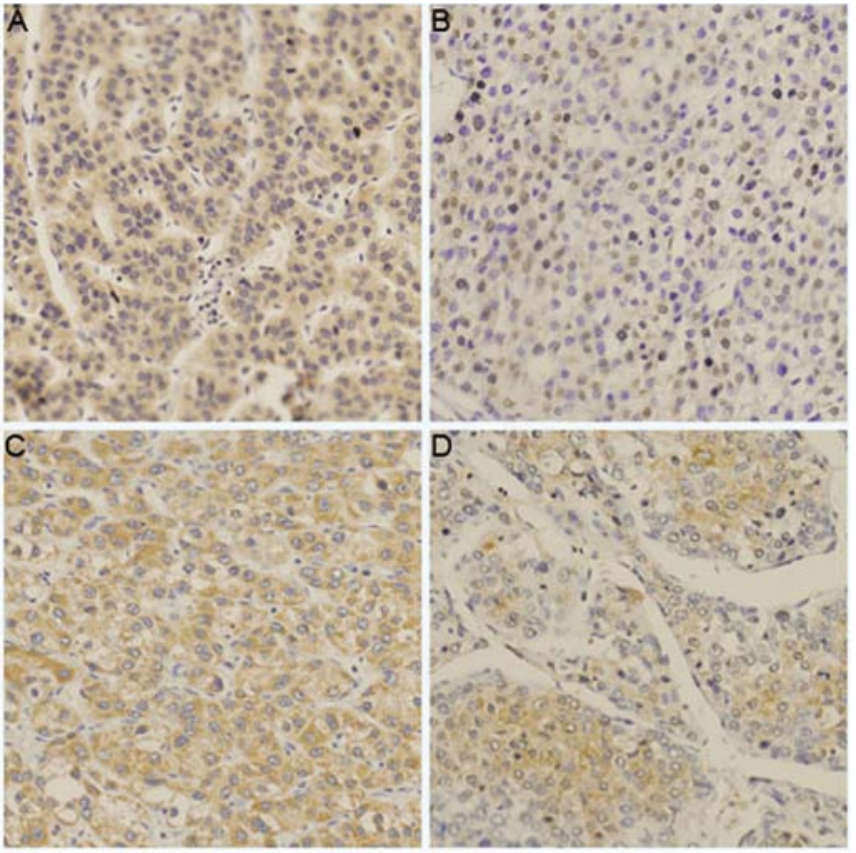

Figure 1. Expression of ART1 in hepatocellular carcinoma tissues with (A) metastasis and (B) without metastasis, as well as the expression of integrin $\alpha 7$ in hepatocellular carcinoma tissues with (C) metastasis and (D) without metastasis.

Correlation between ART1 and integrin $\alpha 7$ expression. ART1 expression was significantly lower in the HCC tissues that were weakly positive for integrin $\alpha 7$ than in the HCC tissues that were strongly positive for integrin $\alpha 7$. The expression of ART1 positively correlated with the expression of integrin $\alpha 7$ in the HCC tissues $(\varrho=0.87629 ; \mathrm{P}<0.01)($ data not shown).

mRNA expression of ART1 and integrin $\alpha 7$ in HCC tissues. The RT-PCR results revealed that the mRNA expression levels of ART1 and integrin $\alpha 7$ were significantly higher in the HCC samples with metastasis than in the HCC samples without metastasis ( $\mathrm{P}<0.05$; Fig. 2).

Immunofluorescence detection of the expression of ARTI on the surface of HepG2 cells. The HepG2 cells were incubated with anti-ART1 antibody, then bound with FITC-labeled secondary antibody. They were then observed under a fluorescence microscope (Olympus), and the results showed green fluorescence on the cell surface and in the cytoplasm. The negative control HepG2 cells did not show green fluorescence. This indicates that ART1 is expressed in HepG2 cells (Fig. 3).

$I C_{50}$ of MIBG in HepG2 cells. The proliferation of HepG2 cells decreased as the concentration of MIBG increased, indicating that MIBG inhibited the proliferation of the HepG2 cells. The $\mathrm{IC}_{50}$ of MIBG in the HepG2 cells was $200 \mu \mathrm{mol} / 1(\mathrm{P}<0.05$; Table II).

Effect of MIBG on the migration of Hep G2 cells. The width of the scratched area in the untreated control group of HepG2 cells at $24 \mathrm{~h}$ was significantly smaller than that at $0 \mathrm{~h}(\mathrm{P}<0.05$; Fig. 4). This indicated that the HepG2 cells had a strong ability to migrate. In the $200 \mu \mathrm{mol} / \mathrm{l}$ MIBG-treated group, the width
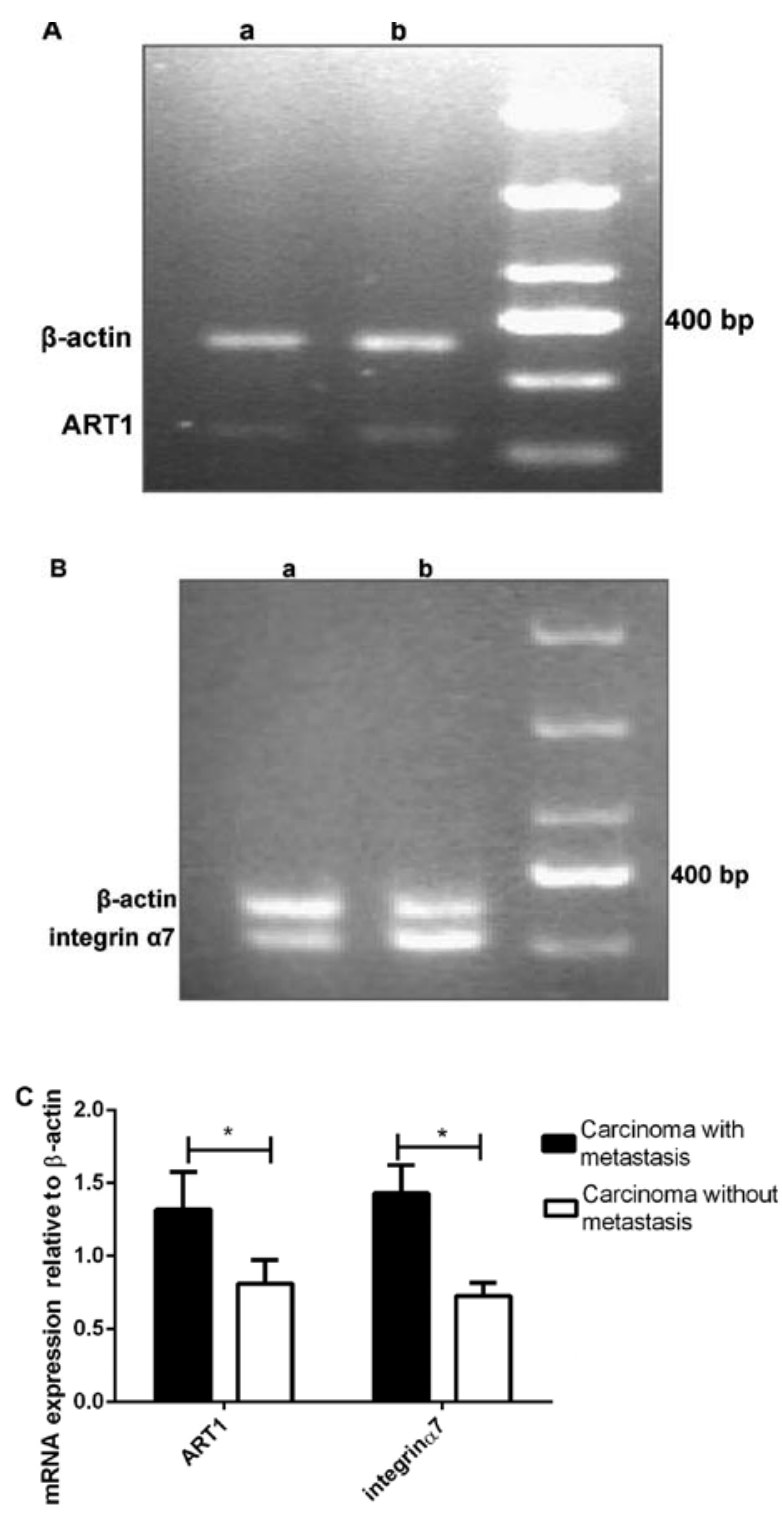

Figure 2. (A) ART1 mRNA expression in hepatocellular carcinoma tissues with/without metastasis; (B) integrin $\alpha 7$ mRNA expression in hepatocellular carcinoma tissues with/without metastasis; (a) hepatocellular carcinoma tissues without metastasis; (b) hepatocellular carcinoma tissues with metastasis. (C) The expression of ART1 and integrin $\alpha 7$ mRNA in the hepatocellular carcinoma tissues with metastasis was higher than that of the hepatocellular carcinoma tissues without metastasis. ${ }^{*} \mathrm{P}<0.05$.

of the scratched area of HepG2 cells at $24 \mathrm{~h}$ was significantly greater than that of the untreated group $(\mathrm{P}<0.05)$. This indicated that HepG2 cell migration was inhibited by MIBG.

Effect of MIBG on the invasion of HepG2 cells. The number of HepG2 cells that underwent invasion through Matrigel in the MIBG-treated group was $147.2 \pm 18.23952$. The number of untreated control group cells was $300.4 \pm 11.9147$. These values were significantly lower in the MIBG-treated group than in the control group ( $\mathrm{P}<0.01 ;$ Fig. 5), indicating that MIBG inhibited the invasive ability of the HepG2 cells.

Effect of MIBG on the protein expression of ART1, integrin $\alpha 7$, FAK, PI3K and UPA in HepG2 cells. Western blot analysis revealed that after MIBG was incubated with the HepG2 cells, 
Table II. Optical density (OD) values at different concentrations and the rate of cell growth inhibition $(\mathrm{SD} \pm \mathrm{s}, \mathrm{n}=5)$.

\begin{tabular}{lcc}
\hline Group & OD & Inhibition rate $(\%)$ \\
\hline Control & $0.853 \pm 0.119$ & \\
MIBG $(\mu \mathrm{mol} / \mathrm{l})$ & & \\
50 & $0.803 \pm 0.071^{\mathrm{a}}$ & 5.86 \\
100 & $0.681 \pm 0.086^{\mathrm{a}}$ & 20.1 \\
150 & $0.597 \pm 0.097^{\mathrm{a}}$ & 30.0 \\
200 & $0.397 \pm 0.049^{\mathrm{a}}$ & 53.0 \\
250 & $0.328 \pm 0.062^{\mathrm{a}}$ & 61.5 \\
300 & $0.233 \pm 0.048^{\mathrm{a}}$ & 72.7 \\
\hline
\end{tabular}

After the hepG2 cells were treated with various concentrations of MIBG, the OD values and inhibition rates were measured by MTT assay. ${ }^{a} \mathrm{P}<0.05$, indicates a statistically significant difference.
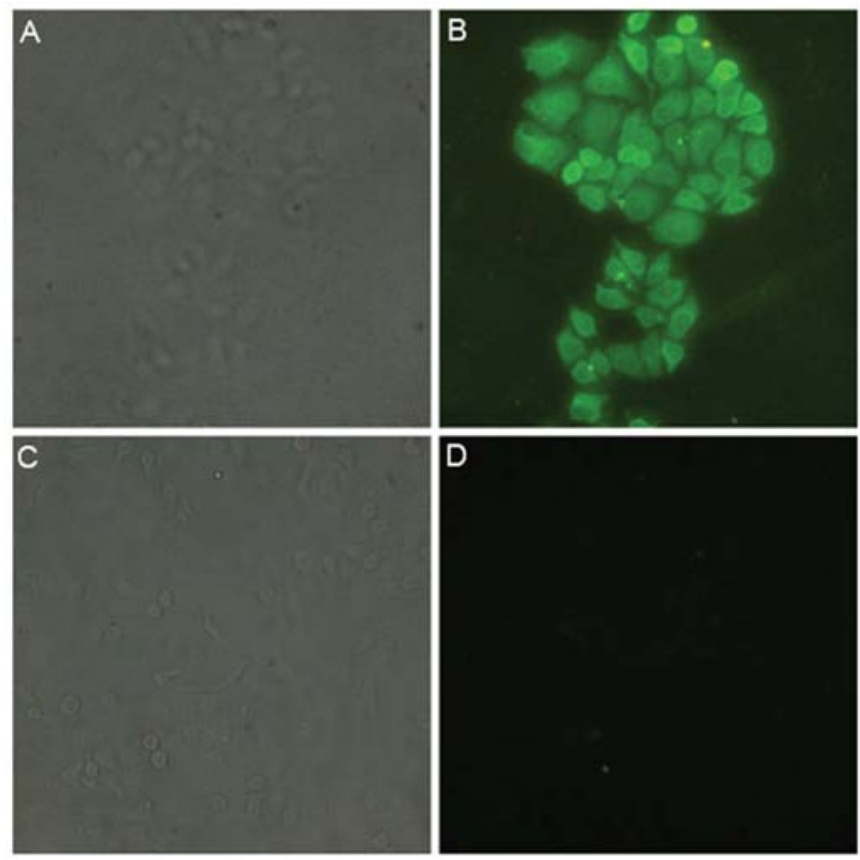

Figure 3. ART1 expression in hepatocellular carcinoma (HepG2) cell detected by the cellular immunofluorescence method (images acquired using a fluorescence microscope; scale bar, $50 \mu \mathrm{m}$ ). (A and B) ART1 antiboby was used as the primary antiboby to detect the expression. (C and D) PBS was used as the negative control.

the protein expression of ART1, integrin $\alpha 7$, FAK, PI3K and uPA in the HepG2 cells was significantly lower compared with the untreated group, and this difference was dose-dependent. The difference was statistically significant $(\mathrm{P}<0.05$; Fig. 6). These results suggested that MIBG inhibited the invasion and migration of HepG2 cells, possibly through the inhibition of the ART1/integrin $\alpha 7 /$ FAK/PI3K/uPA pathway.

\section{Discussion}

Metastatic disease is the most common cause of liver cancerrelated deaths, thus research on effective anti-metastatic drugs
$\mathrm{Oh}$
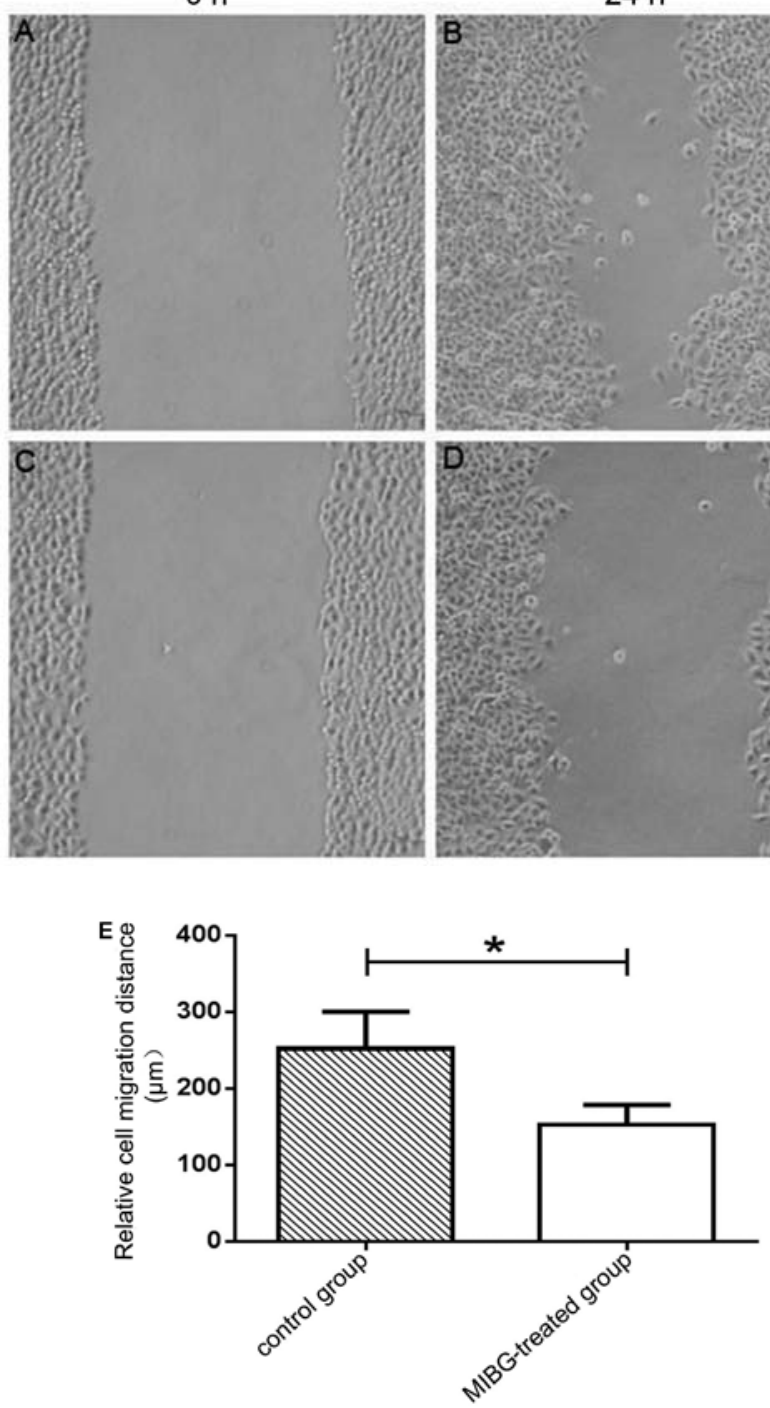

Figure 4. Effect of MIBG on the migration ability of hepatocellular carcinoma (HepG2) cells. (A and B) Control group at 0 and $24 \mathrm{~h}$, respectively; (C and D) MIBG-treated group at 0 and $24 \mathrm{~h}$, respectively (scale bar, $100 \mu \mathrm{m}$ ). (E) The migration distance of the $\mathrm{HepG} 2$ cells in the control group was greater than that of the MIBG-treated group. ${ }^{*} \mathrm{P}<0.05$.

has become a hotspot in drug development. MIBG is currently being used for the diagnosis and treatment of neuroendocrine tumors $(9,10)$.

The invasion and metastasis of tumor cells is a complex process. Adherence to the extracellular matrix (ECM) is the first step in cancer invasion. It is mediated by a specific cell surface receptor. Adhesion molecules are one of the most important molecules in the integrin family.

Integrin adhesion molecules include the non-covalently bound $\alpha$-subunit and $\beta$-subunit. These are connected by heterodimeric transmembrane glycoproteins. There are $18 \alpha$-subunits and $8 \beta$-subunits in the 24 different integrins (11). Integrins $\alpha 3 \beta 1, \alpha 6 \beta 1, \alpha 6 \beta 4$ and $\alpha 7 \beta 1$ mediate cell interaction with the ECM, whereas integrin $\alpha 7 \beta 1$ binds to laminin and promotes tumor cell invasion and migration (12-14).

ART1 is an ADP-ribosyltransferase expressed at a low level in eukaryotes. It is specifically involved in the arginine ADP-ribosylation process. It transfers the ADP-ribose of 

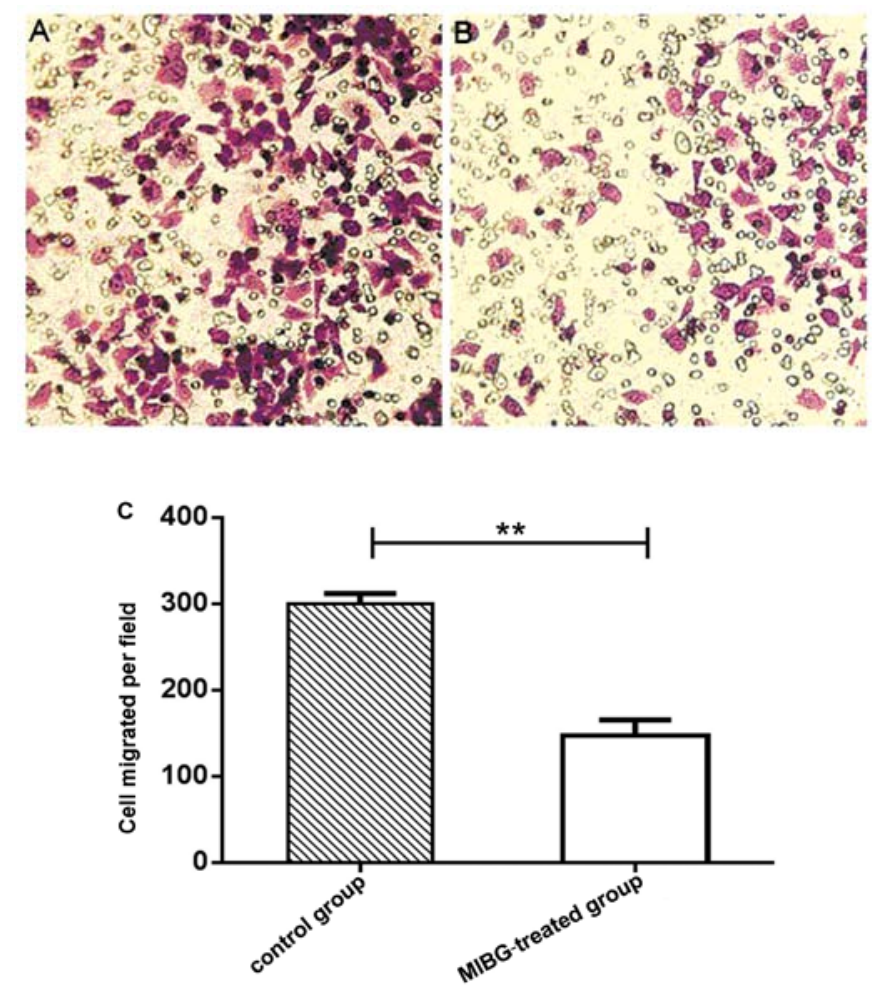

Figure 5. Evaluation of the effects of MIBG on the invasive ability of hepatocellular carcinoma (HepG2) cells by Transwell assay (crystal violet staining; scale bar, $100 \mu \mathrm{m}$ ). (A) Control group; (B) MIBG-treated group; (C) The invasive ability of the HepG2 cells in the control group was greater than that of the MIBG-treated group. ${ }^{* *} \mathrm{P}<0.01$.

$\mathrm{NAD}^{+}$to histidine residues of a targeted protein. This reaction can regulate a variety of important cellular functions, including immune responses, cell adhesion, cell signaling and metabolism (15). However, only $\alpha 7$ subunits can be modified in integrin $\alpha 7 \beta 1$. The $\beta 1$ subunit cannot undergo ribosylation. The ribosylation of integrin $\alpha 7 \beta 1$ causes a conformational change in integrin dimers, leading to greater affinity to a ligand and the enhancement of the function of integrin $\alpha 7 \beta 1$ (16). The maximum rate of migration of tumor cells depends on the concentration of ligands, the levels of integrin expression and affinity between ligands and integrins (17). For this reason, as shown by our results, when integrin $\alpha 7 \beta 1$ was modified with ART1, the ability of the tumor cells to migrate improved.

The integrin signaling pathway involves a variety of protein kinases, such as FAK, proline rich tyrosine kinase 2 (Pyk2) and Src kinase homologs. FAK plays a pivotal role in signal transduction mediated by integrins $(18,19)$. FAK is a non-receptor tyrosine kinase with a molecular weight of $125 \mathrm{kD}$. It binds to the integrin $\beta$-subunit to activate the latter $(20,21)$. FAK binds to and phosphorylates the proline-rich region of the p85 subunit of PI3K. This takes place directly or indirectly through Src, and then the invasion signal is mediated by integrins (22-24). This prompts uPA secretion. It has been reported that inhibitors of PI3K and AKT may reduce the expression of UPA (25-28). uPA is a serine protease, and activated uPA can activate collagenase, which decomposes the collagen matrix. Activated uPA can degrade the basement membrane and extracellular matrix components directly, which promotes tumor metastasis $(29,30)$. Increased levels of uPA and invasive properties of tumor cells
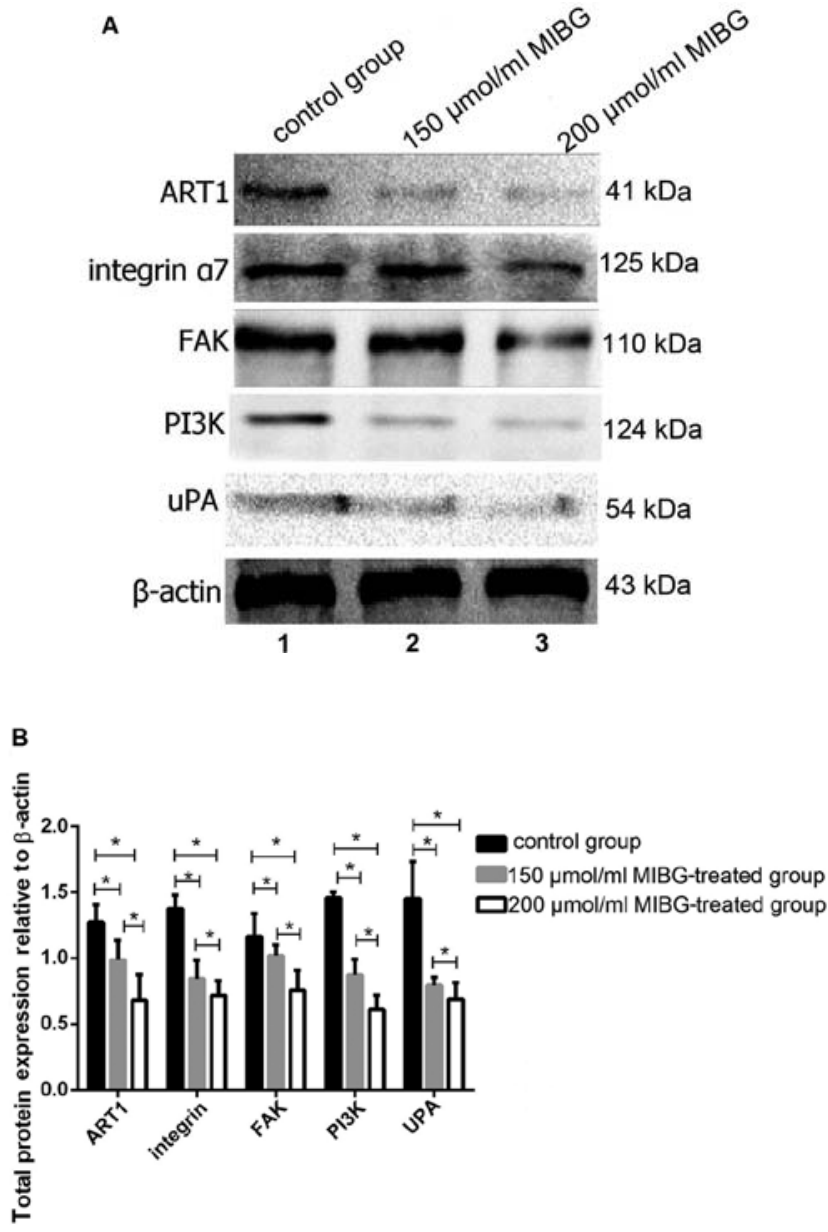

Figure 6. (A) The protein expression of ART1, integrin $\alpha 7$, FAK, PI3K and uPA in the hepatocellular carcinoma (HepG2) cells in the different groups was detected by western blot analysis. Lane 1, control group; lane 2, $150 \mu \mathrm{mol} / 1$ MIBG-treated group; lane 3, $200 \mu \mathrm{mol} / 1 \mathrm{MIBG}$-treated group. (B) The protein levels of ART1, integrin $\alpha 7$, FAK, PI3K and uPA in the control group, $150 \mu \mathrm{mol} / 1 \mathrm{MIBG}-$ treated group and the $200 \mu \mathrm{mol} / 1 \mathrm{MIBG}-$ treated group were determined and compared with each other, and the results showed a significant difference. ${ }^{*} \mathrm{P}<0.05$.

have been found to be closely related to the overexpression of UPA in breast cancer. This is a strong indicator of a poor prognosis (31). In HCC, uPA upregulation is closely related to vascular invasion and intrahepatic metastasis (32).

The results of the present study demonstrated that there was a higher expression of ART1 and integrin $\alpha 7$ in HCC with metastasis than in carcinoma without metastasis. These elevated expression levels were found to positively correlate with each other. As the expression of integrin $\alpha 7$ increased, the expression of ART1 also increased, indicating that the expression of integrin $\alpha 7$ correlated with the expression of ART1. This suggests that these two proteins are synergistically involved in HCC invasion and metastasis. MIBG inhibitedthe expression of ART1, downregulated the expression of integrin $\alpha 7 \beta 1$, continually inhibited its downstream pathway, FAK/PI3K, and further inhibited the expression of uPA. The migratory and invasive capabilities of the HepG2 cells were reduced, suggesting that MIBG inhibited ART1, decreased the secretion of UPA and affected the ability of the HepG2 cells to migrate and invade. 
The expression levels of ART1 and integrin $\alpha 7$ are closely related to the degree of differentiation and metastasis of HCC; thus, these two proteins can be used as indicators for the degree of malignancy and invasiveness of HCC. The role of ART1 and integrin $\alpha 7$ in HCC invasion has important clinical significance for the treatment of liver cancer. MIBG can suppress HCC invasion and metastasis through the inhibition of the expression of ART1 and integrin $\alpha 7$. Based on our observations, MIBG shows promise as a novel anticancer drug for use in the treatment of HCC.

\section{Acknowledgements}

The present study was supported by grants from the Ministry of Education Specialized Research Fund for the Doctoral Program of Higher Education (grant no. 20105503110009) and the Science and Technology Project of the Education Commission of Chongqing (grant no. KJ110322).

\section{References}

1. Di Girolamo M, Dani N, Stilla A and Corda D: Physiological relevance of the endogenous mono (ADP-ribosyl)ation of cellular proteins. FEBS J 272: 4565-4575, 2005.

2. Corda D and Di Girolamo M: Functional aspects of protein mono-ADP-ribosylation. EMBO J 22: 1953-1958, 2003.

3. Zolkiewska A and Moss J: Processing of ADP-ribosylated integrin 7 in skeletal muscle myotubes. J Biol Chem 270: 9227-9233, 1995.

4. Friedrich M, Böhlig L, Kirschner RD, Engeland K and Hauschildt S: Identification of two regulatory binding sites which confer myotube specific expression of the mono-ADPribosyltransferase ART1 gene. BMC Mol Bio 9: 91, 2008.

5. Zhao Z, Gruszczynska-Biegala J and Zolkiewska A ADP-ribosylation of integrin alpha7 modulates the binding of integrin alpha7beta1 to laminin. Biochem J 385: 309-317, 2005.

6. Loesberg C, van Rooij H and Smets LA: Meta-iodobenzylguanidine (MIBG), a novel high-affinity substrate for cholera toxin that interferes with cellular mono (ADP-ribosylation). Biochim Biophys Acta 1037: 92-99, 1990.

7. Yau L, Litchie B and Zahradka P: MIBG, an inhibitor of argininedependent mono (ADP-ribosyl)ation, prevents differentiation of L6 skeletal myoblasts by inhibiting expression of myogenin and p21 $1^{\text {cipl. }}$. Exp Cell Res 301: 320-330, 2004.

8. Song Gl, Tang Y, Wang YL, Xu JX and Xiong W: Effect of ART 1 gene silencing on metastatic potential of mouse colon cancer CT26 cells and its mechanism. Tumor 33: 490-496, 2013

9. Garaventa A, Gambini C, Villavecchia G, et al: Second malignancies in children with neuroblastoma after combined treatment with ${ }^{131}$ I-metaiodobenzylguanidine. Cancer 97: 1332-1338, 2003.

10. Shapiro B: Summary, conclusions, and future directions of $\left[{ }^{131} I\right]$ metaiodobenzylguanidine therapy in the treatment of neural crest tumors. J Nucl Biol Med 35: 357-363, 1990.

11. Rathinam R and Alahari SK: Important role of integrins in the cancer biology. Cancer Metastasis Rev 29: 223-237, 2010.

12. Nishiuchi R, Takagi J, Hayashi M, et al: Ligand-binding specificities of laminin-binding integrins: a comprehensive survey of laminin-integrin interactions using recombinant alpha3beta1, alpha6beta1, alpha7beta1 and alpha6beta4 integrins. Matrix Biol 25: 189-197, 2006.
13. Yao CC, Ziober BL, Squillace RM and Kramer RH: $\alpha 7$ integrin mediates cell adhesion and migration on specific laminin isoforms. J Biol Chem 271: 25598-25603, 1996.

14. Crawley S, Farrell EM, Wang W, et al: The $\alpha 7 \beta 1$ integrin mediates adhesion and migration of skeletal myoblasts on laminin. Exp Cell Res 235: 274-286, 1997.

15. Tsurumura T, Tsumori Y, Qiu H, et al: Arginine ADP-ribosylation mechanism based on structural snapshots of iota-toxin and actin complex. Proc Natl Acad Sci USA 110: 4267-4272, 2013.

16. Zolkiewska A: Ecto-ADP-ribose transferases: cell-surface response to local tissue injury. Physiology 20: 374-381, 2005.

17. Koistinen $P$ and Heino J: Integrins in cancer cell invasion. Cell invasion. Landes Bioscience, 2002.

18. Prasadam I, Farnaghi S, Feng JQ, et al: Impact of extracellular matrix derived from osteoarthritis subchondral bone osteoblasts on osteocytes: role of integrin $\beta 1$ and focal adhesion kinase signaling cues. Arthritis Res Ther 15: R150, 2013.

19. Lim ST, Chen XL, Lim Y, et al: Nuclear FAK promotes cell proliferation and survival through FERM-enhanced p53 degradation. Mol Cell 29: 9-22, 2008.

20. Schaller MD: Biochemical signals and biological responses elicited by the focal adhesion kinase. Biochim Biophys Acta 1540: 1-21, 2001.

21. Zhao J and Guan JL: Signal transduction by focal adhesion kinase in cancer. Cancer Metastasis Rev 28: 35-49, 2009.

22. Thamilselvan V, Craig DH and Basson MD: FAK association with multiple signal proteins mediates pressure-induced colon cancer cell adhesion via a Src-dependent PI3K/Akt pathway. FASEB J 21: 1730-1741, 2007.

23. Shen TL and Guan JL: Differential regulation of cell migration and cell cycle progression by FAK complexes with Src, PI3K, Grb7 and Grb2 in focal contacts. FEBS Lett 499: 176-181, 2001.

24. Xia H, Nho RS, Kahm J, Kleidon J and Henke CA: Focal adhesion kinase is upstream of phosphatidylinositol 3-kinase/ Akt in regulating fibroblast survival in response to contraction of type I collagen matrices via a $\beta 1$ integrin viability signaling pathway. J Biol Chem 279: 33024-33034, 2004.

25. Chandrasekar N, Mohanam S, Gujrati M, Olivero WC, Dinh DH and Rao JS: Downregulation of UPA inhibits migration and PI3k/ Akt signaling in glioblastoma cells. Oncogene 22: 392-400, 2003.

26. Nowicki TS, Zhao H, Darzynkiewicz Z, et al: Downregulation of uPAR inhibits migration, invasion, proliferation, FAK/PI3K/Akt signaling and induces senescence in papillary thyroid carcinoma cells. Cell Cycle 10: 100-107, 2011.

27. Shukla S, MacLennan GT, Hartman DJ, Fu P, Resnick MI and Gupta S: Activation of PI3K-Akt signaling pathway promotes prostate cancer cell invasion. Int J Cancer 121: 1424-1432, 2007.

28. Kargiotis O, Chetty C, Gogineni V, et al: uPA/uPAR downregulation inhibits radiation-induced migration, invasion and angiogenesis in IOMM-Lee meningioma cells and decreases tumor growth in vivo. Int J Oncol 33: 937-947, 2008.

29. Dass K, Ahmad A, Azmi AS, Sarkar SH and Sarkar FH: Evolving role of uPA/uPAR system in human cancers. Cancer Treat Rev 34: 122-136, 2008.

30. Ulisse S, Baldini E, Sorrenti S and D'Armiento M: The urokinase plasminogen activator system: a target for anti-cancer therapy. Curr Cancer Drug Targets 9: 32-71, 2009.

31. Bevan P and Mala C: The role of uPA and uPA inhibitors in breast cancer. Breast Care 3: 1-2, 2008.

32. Chan CF, Yau TO, Jin DY, Wong CM, Fan ST and Ng IO: Evaluation of nuclear factor- $\kappa \mathrm{B}$, urokinase-type plasminogen activator, and $\mathrm{HBx}$ and their clinicopathological significance in hepatocellular carcinoma. Clin Cancer Res 10: 4140-4149, 2004. 